\title{
THE STORIES OF THE STUDENT TEACHER EXTENSIVE READING ACTIVITY AS THEIR EXPERIENTIAL LEARNING: A NARRATIVE INQUIRY
}

\author{
Dheannisa Septiani, Nur Arifah Drajati, Ellisa Indriyani P.H. \\ English Education Department \\ Teacher Training and Education Faculty \\ Sebelas Maret University of Surakarta
}

Email: dheann.sept@student.uns.ac.id

\begin{abstract}
This research aims to explore the stories of student-teacher extensive reading activity as their experiential learning. The participants of this research are two student teacher in their $4^{\text {th }}$ and $8^{\text {th }}$ semester in a University in Surakarta Central Java. The participants consist of 2 female students with range age 20 to 22 years old. Both of the participants were chosen under some consideration of their reading activity. This research is a narrative inquiry-based research. The data of this research was collected through interview sessions with the participants. The finding reveals that, firstly, both of the participants did doing the ten principles of the extensive reading by Day \& Bamford. However, under some conditions, the participants also not following the ten principles. Second, the experiential learning goes through time, the four stages of the experiential learning cycle which are concrete experience, reflective observation, abstract conceptualization, and active experimentation, did not happen once at a time but also repeatedly happen at the time when the process of learning occurs.
\end{abstract}

Keywords: Extensive Reading, Experiential Learning, Narrative Inquiry

\section{INTRODUCTION}

English is one of the six official languages beside China, Rusia, Spanish, Arab, France, in the United Nations. About 61 countries in this world using English as the official language. Which means English has an essential part in every aspect life, such as for communication, education, and technology. In Indonesia, English has been taught since in the elementary until university level. As it is important to be taught in such a young age, English for university students is also important. By conducting observations and interview the researcher found that, most of the university students show some negative attitudes towards learning English, especially reading English book even though many of university learning materials sourced from authentic English books.
As cited in Bonggu \& Sundarsih (2019), the graduated students that prepare to enter college life cannot use the language properly and effectively. Many of the EFL students rarely experienced a situation in which they have to speak in English in daily life, but they might have to read in English quite often since it benefits them in absorbing information which some of it written in English (Eskey, 1996), while actually Reading is one of the basic for all academic disciplines (Lei, Rhinhart, Howard, Cho, 2010). Therefore, students' attitude becomes very important at this point because their attitudes toward the learning situation affect their level of motivation to learn a new language (Masgoret, Bernaus, Gardner, 2001). Reading attitudes defines as "a system 
of feeling related in reading, which causes a learner to approach or to avoid a reading situation" (Alexander and Filler, 1976 p.1). Any negatives attitudes and feelings can stunt the progress of learning a new language. On the other hand, it can be concluded that learners' attitudes affect both their motivation and success in reading by influencing the amount of time that they spent on reading

According to Dawson \& Bamman (1967, p.220-223), there are five factors influencing reading comprehension ability. They are: 1) The readers have different intelligence. The depth of understanding depending on their general capacity to learn; 2) Readers with little experiences possibly have difficulties in understanding the ideas on the text; 3) Readers with unskilled mechanics of reading; 4) Readers are not interested in the topics; and 5) Skills of comprehending.

Reading attitudes acquired through readers' individual experiences (Yamashita, 2013). Extensive reading sometimes called as pleasure reading (Day \& Bamford, 1997), sustained silent reading (Garan \& DeVoogd, 2008), or free reading (Krashen, 2004). Extensive reading is one kind of reading instruction in which provide a large number of reading materials for learners to read independently. According to Day (2004), students are required to read extensively for general meaning, information, and pleasure. By doing extensive reading, learners can develop good reading habits, build up vocabulary knowledge, and enhance positive reading attitudes. Extensive reading is relaxing, informal, and allows students to choose their own books base on their reading level and interest (Chin-Neng et al., 2013).

The researcher formulated the participants' experiences in the format of Kolb's learning cycles. Some benefits come from experiential learning. Experiential learning has been proven to develop communication in the real context of language use (Nation, 2009). Experiential learning also involved in an active learning process by creating, reflecting collaborating and applying their experiences in language use (Nunan, 1993)

There are some previous studies conducted in extensive reading and experiential learning. Chen Chi-Neng, Chen Shu-Chu, Chen Shu-Hui, Wei Shyh Chyi (2013), investigated the impacts of extensive reading of e-book on higher-level EFL students' reading attitude, reading comprehension, and vocabulary. The findings show that the experimental group shows significant better reading attitude, reading comprehension, and vocabulary than the control group.

Boggu, Anita, \& Sundarsih (2019) conducted a research to observe the changes in perception of learners on their autonomous behavior before and after the intervention. The findings showed that the experiential learning cycle activities implicitly increased the learners' autonomous behavior. As what the other researchers have conducted, unfortunately, there is still no research about the exploration of the experiential learning cycle of the experienced extensive reader outside the classroom.

A narrative inquiry approach is used in this study as the method of collecting the data. Narrative inquiry is a phenomenon where people tell their stories by collecting stories and write a narrative about them (Clandinin \& Conelly, 1990). Narrative inquiry provides an opportunity for the researcher to access the personal life of the participant (Kramp, 2004). There have been few narrative inquiry research in the education field, but there are still less narrative studies that explore the experiences of the extensive reader.

Therefore, by considering the explanation above, this research is conducted to explore the experiences and the 
experiential learning cycle of the participants' extensive reading activity outside the classroom by using narrative inquiry as the method.

\section{LITERATURE REVIEW \\ Review on Experiential Learning}

According to the examination of literature, there are variability definitions of experiential learning. The term 'experiential' here is to distinguish between cognitive learning that tends to emphasize cognition is more than affective, and learning behavior theory, which eliminates the role of subjective experience in the learning process.

Experiential learning first introduced as self-centered philosophy of Rogers (1983) to the work of pragmatist and philosopher of science and educations, Dewey (1958). Experiential learning is defined as an activity in which lead the participants in an active environment and build up their knowledge or skill (Yount, 2001; p. 276). The theory of experiential learning is also stated by DA Kolb (1996) after the working ideas of Dewey, Lewin, Piaget. Kolb (1996) stated that experiential learning is the process in which knowledge actualized through the transformation of experiences.

According to Kolb in Sinaga (2013), experiential learning theory is defined from the action to accomplish something based on the experiences that continuously change in order to improve the efficacy of learning outcomes. This approach aims to influence students in threeway. They are: a) to change students' cognitive structure; b) to change students' attitude; c) to expand the skills that they already have. Those three points are related and affect each other because if one element is missing the other two elements will not be effective.

\section{Kolb's Learning Cycle}

According to Kolb, there are four components of learning in the mode of a cycle, which is known as 'Kolb Learning Cycle'. For the best learning result, the learners should actively involve in all four modes, which are: 1) Concrete Experience (CE), 2) Reflective Observation (RO), 3) Abstract Conceptualization (AC), and the last is 4) Active Experimentation (AE).

The first stage of the learning cycles is concrete experience (CE). In this stage, the learner has the experience as the center for the observation. The learner encounters a new experience which has the opportunity for learning. According to Kolb's theory, learners cannot learn by just from observing or reading. The aim of this stage is that the learners actively participate in the experience. They can learn something from it and engage themselves in gaining knowledge from experience. Examples might include exploring and experiencing some events, creating models or some products, play in a role-play, giving a presentation, solving a problem, or playing games.

The second stage is reflective observation (RO). In this stage, the learners reflect on the experience they had before making any judgments. It is important to see any inconsistencies between their experience and understandings. The aim of this stage is for learners to review the situations and the meaning they find after the experience from various perspective. Participants share the result, reaction, and their observation among them. They talk and write about their own experiences, share the reactions and observations then discuss what are they feeling from the experiences, after it reflecting what did the find and related it to be useful in the future.

The activity above followed by abstract conceptualization (AC) stage in which the obtained knowledge from the two stages are integrated, which means that the learners' observations are integrated with rich learning experiences that would support them in 
comprehending and creating the concept. Students relate the experiences they got to the real-world problem, find the truth usually happen about the experiences, and identify what is this could be useful for.

After conceptualizing the concept, the last stage in the experiential learning cycle is active experimentation. In this stage, the learner transforms the newly obtained knowledge from observing and reflecting on the experiences to a stage where the knowledge could be applied in making decisions and problem-solving. Participants discuss how the issue in the experiences can be useful for the future and developing a behavior what could they learn from the experiences.

\section{Review on Extensive Reading}

According to Renandya (1998, p.188), extensive reading is an independent reading large quantity of material for information or pleasure. Extensive reading means reading longer texts, usually for one's pleasure. This activity is a fluency activity, mainly involving global understanding. It is reading activity in which the teacher encourages students to choose for themselves what they like to read and to do so for pleasure and general language improvement.

Reading for enjoyment or reading for pleasure refers to reading activity in which people do as they want to anticipate the satisfaction that people get from the reading activity. Reading for enjoyment also refers to the reading activity in which began first as someone else's request and peoples continuing at doing it because they are interesting with the reading activity. The activity usually including the material that they choose themselves at a time and a place they like the most.

\section{Principles of Extensive Reading}

According to Day and Bamford (1998), an extensive reading also has ten principles:
1) The reading material is easy.

2) A variety of reading material on a wide range of topics must be available.

3) Learners choose what they want to read.

4) Learners read as much as possible.

5) The purpose of reading is usually related to pleasure, information, and general understanding.

6) Reading is its own reward.

7) Reading speed is usually faster rather than slower.

8) Reading is individual and silent.

9) Teachers keep track and guide their students.

10) The teacher is a role model of a reader.

\section{RESEARCH METHOD}

According to Barkhuizen, Benson, and Chik (2014), Narrative inquiry brings storytelling and research together either by using stories as research data or by using storytelling as a tool for data analysis or presentation of findings. Narrative Inquiry is also the title of the major cross-disciplinary journal in the field. Narrative research and narrative study sometimes used as alternative terms. According to Polkinghorne (1995), in narrative analysis, researchers use narrative writing as a method of turning non-narrative data into stories in order to convey their understanding of the meaning of the data.

There are different forms of narrative data. It can be in the form of oral, written or multimodal narrative. In narrative inquiry, interviews are mainly used to produce oral interpretations of language learning and teaching experience. Oral narrative data is collected from open and semi-structured interviews, and then analyzed by processing and transcription of oral interpretations. The participants of this research were chosen on the reason for research purposes. The participants are two experienced extensive readers outside the classroom who are taking English Education Department in 
the $4^{\text {th }}$ and $8^{\text {th }}$ semester from a university in Indonesia. They are chosen under some consideration that are fitting for this research.

\section{RESEARCH FINDINGS AND DISCUSSIONS}

According to the research findings, participants' stages of the experiential learning cycle was processed through time, which will be explained as follows:

\section{Past}

1) Concrete Experience

The concrete experience happened where participants experience their first reading activity, also choosing their preference book. The first participants experienced the enjoyment of reading when she was joining a local storytelling competition. Meanwhile, the second participant did not even realize that she loves to read because she always read for the books brought by her father. This experience influenced by people around them, from their teacher, their friend, their relatives and also from their parents. In this stage also included the time when they are trying online reading for the first time.

2) Reflective Observation

This stage happened where they experienced their first novel or books that unexpectedly suited to their preference, which even explores their emotion as well. They argue that they learn a lot from the stories they read, which coming from various genres. When they find unconfirmed terms that are slowing down their reading, Arael paused her reading and looking for the meaning meanwhile, Anne just guessing the unconfirmed terms and continue her reading.

\section{3) Abstract Conceptualization}

In this stage, the participants realize the purposes of them doing the reading, mostly are to get new knowledge and to fulfilling their curiosity. According to Anne, she is doing the reading because she like it, reading activity able to make her imagine the scenario of something in her mind.

4) Active Experimentation

In this stage, the participants got to know about manga, anime, and kpop. From reading the manga, watching anime, and listening to kpop music makes them having the desire to learn another language besides English. Both of the participants argue that it would be cool to be able to read and write stories in another language besides English.

\section{Present}

\section{1) Concrete Experience}

Most of the experiences happened in the past, but both of the participants stated that every reading material are new to them. Both of the participants sometimes also trying to read new genres or read something unusual from their reading preferences. Therefore, they will share it whether the stories suited to their preferences or not and what they learn from the stories to their friend.

2) Reflective Observation

Today, this stage happened a lot compared to what happened in the past. In this stage, participants had much progress related to their reading activity. Through this stage, participants learn about the difference they have in their experience and their understanding. They realize about what makes their activity different, between before entering college life and after entering college life. Today that after reading, they have always happy to finish it, the quoting of the stories that they put on their social media status/stories. In this stage, they were also realized the most suitable online reading flatform for them and also able to explain what are their differences. From those various kinds of online reading flat-form, they were also having a lot of favorite authors and genres. Both of the participants were also having references of what makes a story 
interesting for them. About the unconfirmed terms, today both of the participants are looking for the meaning depends on the stories they read, if both of the participants need complicated explanation they will pause and looking for the terms, but if they can guess the meaning they will go on reading.

Finally, both of the participants realize the purposes of them doing reading has already changed. Today, their purposes on doing reading are to make them enjoy their spare time, to fulfilling their assignments, to looking for happiness, to self-motivation, they feel happy with this activity, and this activity is a pleasurable activity.

3) Abstract Conceptualization

In this stage, they learn a lot about the moral value they get from the stories they have read. Both of the participants, leaning many things from the stories they have read like, the concept of life, doing good deeds, about how making friends, and many others. Those are helping them in making any decision they need to make today. In this stage, their interaction between readers is work deeper than before that happen in the past. Today, the participants are having interaction or discussing stories broader and deeper. They also start to communicate or discuss with the author of the books through social media or the online reading flat-form they have. They were now able to like, voting, and also giving feedback to the stories they have read.

4) Active Experimentation

In this stage, the participants start to implement the knowledge they have after reading activity. Both of the participants now implementing any moral value they got from reading stories. Both of the participants also now have become a reader and also a writer in online reading flat-forms. They also sometimes drawing the character they read in the book if they like them. Most importantly, both of the participants are learning another language besides English and start to use them to write a short story. Now that they are slowly understanding and use another language to write or read something besides English.

Related to their assignments, they do not feel any burden when the assignment related to the reading activity. Whether they have to write the resume of books or they, have to understand the concept of something. According to them, they will do it happily and do not feel any difficulties.

\section{Future}

For future use, their learning experiences from the reading activity most likely worked in active experimentation. First, they will use any new knowledge they got to improve their writing stories and also to improve their self as a human being. Second, learning another language will help them to achieve their future goals as the translator and as a writer as well.

\section{IMPLICATIONS}

This study implies that the teacher should be aware that every student had different reading materials. The teacher should be able to explore students' reading experiences and use them in the learning and teaching process. Students can also use extensive reading to improve their reading proficiency. By using extensive reading, students had developed a reading habit, gained more confidence in reading as they challenged themselves to read a higher level of reading materials. Besides, they had improved reading attitudes, became motivated to read, and also have been more prepared for further academic courses because they have read a large sum of materials. The experiences of their learning process also focused on the affective and social aspects of the participants. Therefore learning experiences also improved their self- 
confidence and became an autonomous learner.

\section{CONCLUSION AND SUGGESTION}

Based on the result and the findings which discussed, the conclusion suggestion of this research are:

1) The extensive reading they did outside the classroom does not always match with the ten principles of extensive reading by Day \& Bamford. Most of the extensive reading activity in this research was done according to the way which participants like to do.

2) The cycles of experiential learning do not only happen once at a time. According to the finding of this research, the cycles repeatedly happen at one time or also at another time. The range of this experiential learning could way beneath the past time and also for the future if the researcher able explores the participants' experiences well.

The finding of the study suggests for further investigation to explore issue related to this study critically. Future researchers could investigate more deeply about expensive reading and experiential learning since there is a wider range of learning experience need to explored more. For this reason, this research is meant to be useful for:

\section{1) English Teachers}

The teacher can develop this research into a case study class or using other research method to apply the topics related to this study into their class. The teacher should facilitated their students in their reading activity so that they able to explore more about student reading activity in reading. The teacher should become a role model of the reader where the teacher should also join any discussion or sharing any ideas with their student.

2) Students
The student should realize that extensive reading are also one of the best ways to improve their reading skill as well as another skill. The student should try implemented extensive reading in their learning process so they can get the experience of learning from it. As the center of learning, the student should improve their reading skills to achieve better achievement. Experiential learning method facilitated the students to explore more their learning experiences in reading activity.

3) Other researchers

Thus the study is limited in the exploring student teacher experiential learning on extensive reading activity. Hopefully, other researchers can uses it as a reference or any consideration for further study. The other researchers can use this research by using different method to higher or lower level learners. The other researcher can also use experiential learning to explore learners' learning experiences on other skills.

4) Future Parents

For parents, this activity could beneficial for their children if they implemented it since their children was a kid. Besides, parents should also become a role model of the reader for their children. Without realizing, the activity could grow a love of reading to their children, which will be beneficial for their future, especially for their academic purposes.

\section{BIBLIOGRAPHY}

Alexander, J. E., \& Filler, R. C. (1976). Attitudes and reading. Newark, DE: International Reading Association.

Bamford, J., \& Day, R. R. (2004). Extensive reading activities for teaching language, Cambridge University Press.

Barkhuizen, G., Benson, P., Chik, A. (2014). Narrative Inquiry in Language 
Teaching and Learning Research. Second Language Acquisition Research Series. Routledge, Ney York.

Bonggu, A. T., Sundarsih, J. (2019). An Experiential Learning Approach to Fostering Learner Autonomy Among Omani Students. Journal of language teaching and research, 204-205.

Chen, C.N., Chen S.C., Chen, G.h., Wey, S.C. (2013). The Effects of Extensive Reading Via E-Books On Tertiary Level EFL Students' Reading Attitude, Reading Comprehension And Vocabulary. TOJET: The Turkish Online Journal of Educational Technology, 12 (2).

Clandinin, D. J., \& Connelly, F. M. (2000). Narrative Inquiry: Experience and Story in Qualitative Research. San Francisco, CA: Jossey-Bass.

Connelly, F.M., \& Clandinin, D.J. (1990). Stories of Experience and Narrative Inquiry. Educational Researcher, 19(5), 2-14.

Creswell, J. W. (1998). Qualitative Inquiry and Research Design: Choosing Among Five Traditions. London: SAGE Publications.

Day, R. R., \& Bamford, J. (1998). Extensive Reading in the Second Language Classroom. Cambridge: Cambridge University Press.

Day, R. R., \& Bamford, J. (2002). Top Ten Principles For Teaching Extensive Reading.

Devine, \& D. E. Eskey.(1996). Interactive Approaches to Second Language
Reading. Cambridge University Press, USA.

Dewey, J. (1938). Experience and Education. New York, NY: Macmillan.

Eskey, D. E. (1996). Holding in the Bottom: An Interactive Approach to the Language Problems of Second Language Readers.

Grabe, W., \& Stoller, F. L. (1997). Reading and Vocabulary Development in $A$ Second Language: A Case Study. In J. Coady, \& T. Huckin. (Eds.), Second language vocabulary acquisition: A rationale for pedagogy. (pp. 98-122). Cambridge: Cambridge University Press.

Kolb, A.Y., and D.A. Kolb. 2005. Learning Studies and Learning Spaces: Enhancing Experiential Learning in Higher Education. Academy of Management Learning and Education, 4 (2).

Kolb, D. A. (1984). Experiential Learning: Experience as the Source of Learning and Development (2).

Krashen, S. (1982). Principles and Practice in Second Language Acquisition. Pergamon Press, New York.

Krashen, S. (1993). The Power of Reading. Englewood, Col.: Libraries Unlimited, Inc.

Lei, S. A., \& Rhinehart, P. J., \& Howard, H. A., \& Cho, J. K. (2010). Strategies for Improving Reading Comprehension among College Students. Reading Improvement, 47(1), 30-42. 
Masgoret, A-M., Bernaus, M., \& Gardner, R. C. (2001). Examining the role of attitudes and motivation outside of the formal classroom: A test of the mini ATMB for children. In Z. Dörnyei, \& R. Schmidt (Eds.), Motivation and second language acquisition (Technical Report \#23, 281-295). Honolulu: University of Hawaii, Second Language Teaching and Curriculum Center.

Nunan, D. (1999). Second language teaching \& learning. Boston: Heinle \& Heinle Publishers.

Nuttall, C. (1996). Teaching Reading Skills in A Foreign Language: Heinemann Pr.

Powell, S. (2005). Extensive Reading and Its Role in Japanese High Schools. The Reading Matrix, (5).

Yamashita, J. (2013). The Effects Of Extensive Reading On Reading Attitudes In A Foreign Language. Reading in Foreign Language, 249-250. 